\title{
The problem of labour resources as a development barrier to the Polish economy - the application of the Delphi method
}

\author{
ANNA KONONIUK, JULIA SIDERSKA, ALICJA E. GUDANOWSKA \\ Faculty of Engineering Management \\ Bialystok University of Technology \\ 45A Wiejska Street, Bialystok 15-351 \\ POLAND \\ KATARZYNA DĘBKOWSKA \\ Polish Economic Institute \\ 87 Al. Jerozolimskie Street, Warszawa 02-001 \\ POLAND
}

\begin{abstract}
Constant and unpredictable changes on the labour market are causing a direct impact on the actions and measures taken by employees and organisations, since these have to adapt to new emerging models in order to ensure the continuity of their activity. This study aimed to obtain experts' opinion and consensus on thirteen research theses relating to the labour market, economic growth and education system in Poland. The research addressed, among other things, the issues of work ethos, adjustment of professional qualifications to the rapidly changing needs of the labour market, employing foreigners, return from abroad of highly qualified specialists, the situation of disabled people on the labour market and flexible forms of employment. The study presented in the article was based on the Delphi method. The method is a kind of expert study in which intuitive expert opinions are treated as a legitimate contribution to the formulation of a vision of the future of the research subject. The results obtained in the research may be interesting for political decision-makers, public administration employees, employees of district and provincial labour offices as well as all those interested in the Delphi method and the future of the labour market.
\end{abstract}

Key-Words: labour resources, Polish labour market, Delphi method, future of the labour market

Acknowledgment: This research is supported by Bialystok University of Technology and financed from a subsidy provided by the Minister of Science and Higher Education.

Received: August 1, 2020. Revised: November 30, 2020. Accepted: December 31, 2020. Published: January 12, 2021

\section{Introduction}

According to theory of economy, one of the factors of economic growth is work. It is the labour resources in a given economy that determine significantly its potential. At the same time, the nature of work and the related expectations of employers are constantly changing in the modern market. It is noticeable that there is a need for employees of the future, who learn throughout their lives, are able to analyze the market environment, constantly adapt to its changing conditions, but also create professional development opportunities on their own [28]. The labour market has thus become a dynamically changing environment, and its specificity may be determined by various factors, such as the number of enterprises operating in it, their diversification, the existing technical infrastructure, migration processes, but also the availability of investment trends, or the quality of soils or the road network in a given geographical area [14]. The labour market is also the main recipient of the results of the education system in a given country. Education, professional knowledge and appropriate professional skills are among the key factors determining an employee's usefulness on the labour market [44]. At the beginning, for the purposes of the research presented in this article, certain determinants and relations of the contemporary labour market in the context of economic development and education are presented, which with the support of expert knowledge during the research process have been transformed into the theses of Delphi research.

One such determinant is the work ethos. It is understood as a set of values and norms characteristic for a given social group or for the whole society, referring to the fundamental value that is work. Nowadays, we can observe the phenomenon of boasting about the ability not to work, while possessing considerable wealth, as a 
life attitude that surpasses work and is a way of a higher quality of human existence. With such a social attitude, the work ethos is increasingly fading away. According to Kapias and Polok, it is reduced to an archaic attitude that seems to be longer necessary for anyone [23], [47]. This also brings risks for the education system.

Another issue are educational and professional choices that should be independent of social support. An integral view of the education system, which combines the various objectives pursued by the state today, stresses the need to ensure that individual opportunities for good education are independent of personal or socio-economic circumstances [11].

A further feature of the changing labour market is the emphasis on the importance of vocational training as vocational education aims to develop competences to empower potential employees to find gainful employment [40]. It would be highly desirable for the vocational training system to ensure the adjustment of professional qualifications to the rapidly changing needs of the labour market with the hope that the mismatch between the education profile and the needs of the labour market will not hinder economic growth. As stressed by Santoso and Hadi Putra, that mismatch may materialize if higher education institutions do not respond quickly to workforce trends.

One of the aspects frequently raised in relation to domestic employment is the issue of migration and the growing importance of migrants in the labour markets, especially in countries considered highly developed. A lack of skilled workers is recognised in many economic sectors. As a result, these are being supplemented by immigrants, and this increasingly concerns the Polish labour market as well. Still, however, the employment of foreigners in Poland (mainly coming from Ukraine) largely includes employment in entry-level

positions, usually not requiring high qualifications [2]. A very small number of foreigners settle in Poland for a longer period of time, immigrants represent a minority of the permanent residents of Poland [26].

Contemporary migration is liquid, so it is based on the temporality, flexibility and unpredictability of life's trajectories. In the short term, going abroad allows, above all, to improve the economic situation of the migrant. In the longer term, after coming back to the country, the experience of liquid migration can be a positive and important element of a professional career, also improving the situation in the labour market in the country (in terms of salary and position) [50], [18]. People returning from migration find themselves on the Polish labour market much better than before leaving. As it is indicated in the literature, a small percentage of those leaving Poland leave the country with the intention of staying abroad permanently, and in recent years the number of returnees exceeds the number of those leaving. In the case of professions requiring the highest qualifications, as in the case of medical doctors, the outflow of workers even increases the salary pressure in the country. It is worth noting that a number of actions are currently being taken in Poland to solve the problem of the brain drain [22]. The vast majority of Polish migration processes concern young people dynamically changing group in the labour market [6], [7]. One of the key actions in relation to this group is to reduce the mismatch between the competences of young people and the needs of the labour market and to support the education system [41].

Apart from the possibility of employment in the country, the resources of the national labour force are also strongly influenced by the quality of life. It should be noted that there is a significant correlation between the level of education and the sense of well-being [46]. In groups with a higher level of education, a higher percentage of people are satisfied with life than in less educated groups [15]. Education allows to achieve a satisfactory salary, recognize the prospects for professional development, reduce the risk of unemployment and increase social prestige. Also for the economy as a whole, the competences of employees are an essential factor in improving productivity and competitiveness [44]. Positive changes taking place in the education system have improved the level of education of the society in Poland. In the years 2014-2018 a systematic increase in the share of people with higher education in the population aged 15-64 was observed. At the same time, research results confirm that the level of salary increases with the level of education [4], [9].

The current labour market is strongly influenced by technological progress and so-called Fourth Industrial Revolution, but still the analysis of technological trends such as automation, and robotization is treated marginally in the process of educating [27]. The ability to self-educate should be thus considered very important in this context. It should be here stressed that the education system focused on educating the intellect and logical thinking, has the greatest influence on the possibility of accomplishment the vision that education system will create an entrepreneurial attitude [49], [1]. Under the limited number of hours dedicated to the 
teaching of entrepreneurship, the most important is the careful selection of objectives and content of entrepreneurship education [38], [36] , [17]. The lack of support for education of the most talented students is the barrier that strongly limits the possibility that the education system will create an entrepreneurial attitude. Companies need to operate more flexible and adapt to the changes faster. It has resulted in a number of job opportunities based on forms other than the traditional employment contract. This diversity is dictated by the need to adapt to the new conditions, skills and expectations, both on the part of employers and employees [24]. The rapidly progressing automation and digitization of the economy [42] is however an opportunity for people in a special situation on the labour market (e.g. the disabled, the elderly) to use their potential [19]. Education system has a potentially pivotal role to play in the social and economic development of the regions and the process of shaping innovative policies and smart specialisations in particular. The researchers stress also that the development of the education system should be aimed at promoting smart specialization [25].

The research presented in the article was based on the Delphi method. The Delphi method is a kind of expert study in which intuitive expert opinions are treated as a legitimate contribution to the formulation of a vision of the future on a research subject [35].

The article consists of five main parts. In the first part, the authors presented the general context of their research enlisting changes that are visible on the labour market. The second section of the article is devoted to the presentation of the literature review on the Delphi method and its applications for the needs of the labour market which proved to be more indirect than direct. The third section revolves around the demonstration of the research methodology consisting of five main stages. The aim of the fourth section is to present the main results of the research in relation to: the indicators of importance of the theses for the country's economic growth, level of expertise declared by the experts, experts' estimated implementation time of the issues described in the theses and values of indicators of significance of factors facilitating the implementation of the theses as well as the indicators of significance of barriers hindering the implementation of the theses. The last section of the article is devoted to the presentation of discussion and the summary of the results.

\section{Delphi method - literature review}

Delphi method is usually applied to predict the development of long-term phenomena in a situation of complexity and uncertainty, especially when: (i) the predicted phenomena do not yield to the analytical techniques characteristic for forecasting, (ii) there is no reliable data on the predicted processes or (iii) external factors have a determining influence on the predicted phenomena [29]. The key features of the method include: multi-stage procedure, anonymity, providing feedback, independence of experts' views. Delphi method assumes at least a repeated survey of the same group of experts [29]. In the classical approach, the Delphi study is preceded by formulation of Delphi theses and ancillary questions. The Delphi thesis is referring to the future description of dependences between issues arising from the field of the study and a setting determined by the goal of the research carried out. In the simplest terms, it is a research question relating to the future presented in the form of a thesis (the description of dependences). Ancillary questions include items such as, among others assessment of the level of expert knowledge, the time to implement the thesis, factors conducive to the realization of the thesis, barriers of its implementation and the expected effects of the thesis [39].

Although the application of the method or its modifications for various research fields is quite popular in the scientific journals [13], [3], [33], [16], [20], [30], [48], [45] its usage for creating a common vision of the labour market is rather scarce. In the existing published works on the subject, one can find publications which, more indirectly than directly, describe the problems of using the Delphi method to identify the visions of the labour market in the long term perspective. Lucena et al. describe the application of the method for the analysis of cross-cutting competences and emphasize that employees have to adapt to new emerging models just to survive on the labour market [21]. The application of the Delphi method for the identification of competences is also described by Chiu et al. [5]. The authors used the method for constructing evaluation indicators of design students' core competencies. An interesting example of the application of the Delphi method for the aligning higher education programs to labour demands is depicted by Felisardo et al. [12]. On the basis of the state of the art and government guidelines, 336 national career coordinators indicated a competency gap between competences required by the market and those trained in Higher Education Institutions (HEIs). Mamagi et al. on the basis of the Delphi method established an 
importance ranking on the new competences, capabilities and skills that the lifelong learning Spanish trainers must possess nowadays. The usage of e-Delphi method allowed to establish the ranking of the importance criteria, sub-criteria and indicators and to eliminate the least valued. The minimum level necessary to reach the consensus among experts has been achieved in the second round [32]. An noteworthy application of the Delphi method was evidenced by Moreno and Roda. They present results of a study on the relationship among youth, work, and identity construction. The goals of their work were twofold. The first one was to examine the working conditions of Spanish youth and their impact on individuals' biographies. The second one was to analyze the effect of labor -related variables on change of identity elements in Spanish youth [34].

This article fills a research gap in the use of the Delphi method to assess changes that may occur in the Polish labour market, particularly with regard to such issues as adjustment of professional qualifications to the rapidly changing needs of the labour market, employing foreigners, return from abroad of highly qualified specialists, the situation of disabled people on the labour market and flexible forms of employment.

\section{Research methodology}

The adopted research methodology consisted of five stages which are presented in figure 1.

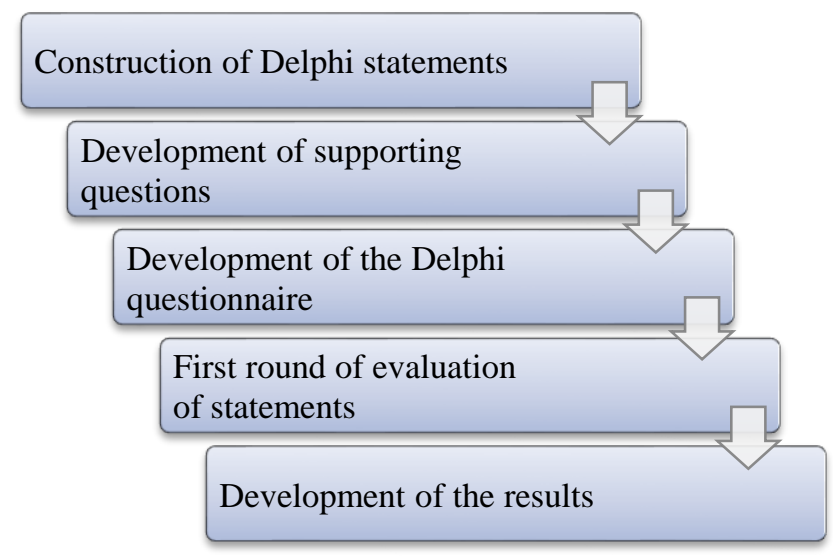

Fig. 1. Research methodology

Source: own elaboration.

At the first stage of the research procedure, thirteen research theses were developed in relation to the labour market, economic growth and educational system (table 1). At the second stage the developed theses were verified by the Key Experts from the Education Team at the Institute for Market, Consumption and Business Cycles Research National Research Institute (IBRKK-PIB). The Key Experts also prepared supporting questions to the theses, in particular with regard to facilitating factors and barriers to the implementation of the theses. At the third stage of the research procedure a Delphi questionnaire was developed and at the fourth stage the first round of the Delphi research was conducted. The fifth stage of the presented methodology involved the elaboration of the results of the first round of the research.

The Delphi questionnaire was developed by the authors with reference to thirteen theses identified by the experts during the expert workshop. The authors, together with the experts, also pointed out facilitating factors and barriers to the implementation of the theses relating to labour resources and the future of the labour market in Poland. It is worth emphasizing that the whole adopted research procedure could be applied to study these phenomena also in other countries. The respondents participating in the survey were asked to answer five identical questions prepared for each of the thirteen theses. As the questionnaire was completed by experts with different levels of knowledge relating to particular theses, the authors requested them to subjectively determine the knowledge of the thesis on a given issue (very high, high, average, low, no knowledge).

Table 1. Theses of the Delphi research relating to the future of the labour market

\begin{tabular}{|c|c|}
\hline Thesis 1 & $\begin{array}{l}\text { The education system will be based on the } \\
\text { work ethos }\end{array}$ \\
\hline Thesis 2 & $\begin{array}{l}\text { Educational and professional choices will be } \\
\text { independent of the available forms of social } \\
\text { assistance (e.g. temporary benefits, family } \\
\text { allowances) }\end{array}$ \\
\hline Thesis 3 & $\begin{array}{l}\text { The vocational training system will ensure the } \\
\text { adjustment of professional qualifications to the } \\
\text { rapidly changing needs of the labour market }\end{array}$ \\
\hline Thesis 4 & $\begin{array}{l}\text { The mismatch between the education profile } \\
\text { and the needs of the labour market will not } \\
\text { hinder economic growth }\end{array}$ \\
\hline Thesis 5 & $\begin{array}{l}\text { The employment of foreigners will not lead to } \\
\text { an increase in unemployment among Poles } \\
\text { seeking work }\end{array}$ \\
\hline Thesis 6 & $\begin{array}{l}\text { The employment of foreigners will not affect } \\
\text { the salaries of Poles }\end{array}$ \\
\hline Thesis 7 & $\begin{array}{l}\text { The return from abroad of Polish highly } \\
\text { qualified specialists will contribute to } \\
\text { economic growth }\end{array}$ \\
\hline Thesis 8 & $\begin{array}{l}\text { Living conditions and employment } \\
\text { opportunities in the country will stop the } \\
\text { migration of highly qualified professionals }\end{array}$ \\
\hline Thesis 9 & $\begin{array}{l}\text { Obtaining education in Poland will ensure high } \\
\text { quality of life }\end{array}$ \\
\hline Thesis 10 & $\begin{array}{l}\text { Automation and digitisation of the economy } \\
\text { will popularise the use of the potential of } \\
\text { people in a special situation on the labour } \\
\text { market (e.g. the disabled, the elderly, carers of } \\
\text { dependent persons, inmates of penitentiary } \\
\text { units) }\end{array}$ \\
\hline
\end{tabular}




\begin{tabular}{|c|c|}
\hline Thesis 11 & Flexible forms of employment will be common \\
\hline Thesis 12 & $\begin{array}{l}\text { The education system will create an } \\
\text { entrepreneurial attitude }\end{array}$ \\
\hline Thesis 13 & $\begin{array}{l}\text { The development of the education system will } \\
\text { be focused on promoting smart specialisations }\end{array}$ \\
\hline
\end{tabular}

The questionnaire also requested experts to determine the significance of particular theses for economic growth in Poland (very high, high, average, low, very low, hard to say). Additionally, the respondents were asked to indicate a time perspective for the implementation of the issues raised in each thesis. The perspective was defined as follows: until 2023, from 2023 to 2028, from 2029 to 2034, after 2035, hard to say, the issue described in the thesis will never take place.

The experts then assessed the impact of the identified factors on the feasibility of individual theses. The factors subject to the assessment were:

- systemic, consistent and effective pro-family policy of the state;

- humanisation of culture (building respect for people);

- maintaining and developing social and national ties;

- the education system focused on educating the intellect, logical thinking;

- cooperation of educational institutions with business in the field of vocational training;

- self-education skills;

- feeling of safety;

- the education system focused on the development of character traits desired in professions;

- a rational migration policy.

The experts were asked to indicate their choice from among the following degrees of influence of factors on the implementation of the theses: very high, high, average, low, very low, hard to say.

The subject of the respondents' assessment at the last stage of the survey was also to indicate the importance of the identified barriers in relation to the implementation of the issues described in the theses. The barriers subject to the assessment were:

- lack of exploitation of the potential of the most talented graduates by employers;

- lack of profound general education, consumptionism, the money cult;

- building a multicultural society (no integration of immigrants into Polish society);

- limited communication between entrepreneurs and the representatives of the education system in the field of vocational education;

- lack of respect for your own country.
The experts' task was to determine the significance of these barriers from among the following: very high, high, average, low, very low, hard to say.

The experts for the Delphi research were selected with the "snowball" method. The experts invited to the survey nominated further experts to participate in the study until the target group is formed. The survey was attended by 34 experts. The group of respondents consisted of 22 women and 12 men representing such areas of professional activity as: science and education ( 25 respondents), administration (5), NGOs (3) and business (1). The age structure of the respondents was diverse. It was dominated by $36-$ to 45-year-olds (12) and 46- to 55-year-olds (8). The expert group was composed of representatives of the older generation (6 people aged 56-65 and 3 being over 65) and young people (under 35 - 5 respondents). Two questionnaires were excluded from the analysis due to significant data gaps.

The first round of the Delphi research was carried out using the CAWI technique (Computer Assisted Web Interviewing). The selected technique has many advantages, and the most important ones include:

- automatic (made by the system supporting the survey) verification of logical correctness of the entered data;

- automatic saving of survey results on the server, which makes the analysis process easier and faster;

- possibility of conducting surveys in case of groups of respondents dispersed over a large geographical area.

In order to simplify the analysis of a large volume of data collected as a result of the survey, some variables of the questionnaire were presented in the form of indicators that synthesise and organise the results of more detailed observations.

In order to determine the strategic importance of particular theses for the economic growth of the country, indicators of significance (Is) were determined according to the following formula [7], [10], [35]:

$I_{S}=\frac{n_{V H} \cdot 100+n_{H} \cdot 75+n_{A} \cdot 50+\cdot 25 n_{L}+0 n_{V L}+0 n_{H S}}{n-n_{H S}}$

where:

$n_{V H}$ the number of responses very high,

$n_{H}$ the number of responses high,

$n_{A}$ the number of responses average,

$n_{L}$ the number of responses low,

$n_{V L}$ the number of responses very low,

$n_{H S}$ the number of responses hard to say,

$n$ the number of all responses.

The indicator takes values from 0 to 100 ; the closer the value of the indicator to 100 , the more 
strategic importance is assigned to a given thesis for the examined area.

Moreover, the indicators relating to the degree of influence of factors ( $I f)$ on the execution of the thesis were determined. The indicators were calculated according to the formula [7], [10], [35]:

$I_{f}=\frac{n_{V H} \cdot 100+n_{H} \cdot 75+n_{A} \cdot 50+\cdot 25 n_{L}+0 n_{V L}+0 n_{H S}}{n-n_{H S}}$

where:

$n_{V H}$ the number of responses very high,

$n_{H}$ the number of responses high,

$n_{A}$ the number of responses average,

$n_{L}$ the number of responses low,

$n_{V L}$ the number of responses very low,

$n_{H S}$ the number of answers hard to say,

$n$ the number of all answers.

The authors also determined indicators relating to the importance of barriers to the implementation of the issues raised in the thesis of barriers $(I b)$. The indicators were calculated according to the formula below [7], [10], [35]:

$I_{B}=\frac{n_{V H} \cdot 100+n_{H} \cdot 75+n_{A} \cdot 50+\cdot 25 n_{L}+0 n_{V L}+0 n_{H S}}{n-n_{H S}}$

where:

$n_{V H}$ the number of responses very high,

$n_{H}$ the number of responses high,

$n_{A}$ the number of responses average,

$n_{L}$ the number of responses low,

$n_{V L}$ the number of responses very low,

$n_{H S}$ the number of responses hard to say,

$n$ the number of all responses.

The indicators assume values from 0 to 100 . The numerical level of the indicator above 50 means a high degree of factor facilitation in case of If and hinderance to the implementation of the thesis for $I b$. Indicators below 50 mean a low degree of facilitation of a given factor and hindrance to the implementation of the thesis.

\section{Results}

The experts participating in the first stage of the research provided their level of knowledge of the issues described in the theses. The summary of the declared level of knowledge is presented in figure 2 . The highest level of knowledge of the issue was declared in case of the influence of obtaining education in Poland on the quality of life (the issue discussed in thesis 9). Twenty-four respondents (over $70 \%$ of the respondents) indicated that they have a high or very high level of knowledge of this phenomenon. In the case of issues concerning the education system to be based on the work ethos (thesis T1) and its potential to create an entrepreneurial attitude (thesis T12), the experts indicated a high or very high level of knowledge of the issue in less than 60\% of cases (in both theses 19 people). More than half of the experts surveyed indicated high or very high level of the issue in the case of: mismatch of the educational profile to the needs of the labour market and the impact of this phenomenon on economic growth (T4), the vocational education system and its impact on the adjustment of professional qualifications to the rapidly changing needs of the labour market (T3) and the orientation of the development of the education system to promote smart specialisation (T13).

Analysing the importance of particular theses for the economic growth of the country, the authors compared the obtained results (fig. 3). According to formula (1), the indicators of importance of the theses for the country's economic growth were also determined (table 2).

Table 2. Indicators of importance for the economic growth of the country

\begin{tabular}{|c|c|}
\hline Thesis & $\begin{array}{c}\text { Indicators of importance for the } \\
\text { economic growth of the country }\left(I_{S}\right)\end{array}$ \\
\hline T1 & 77 \\
\hline T2 & 69 \\
\hline T3 & 80 \\
\hline T4 & 73 \\
\hline T5 & 66 \\
\hline T6 & 72 \\
\hline T7 & 80 \\
\hline T8 & 90 \\
\hline T9 & 82 \\
\hline T10 & 64 \\
\hline T11 & 72 \\
\hline T12 & 79 \\
\hline T13 & 80 \\
\hline
\end{tabular}

Source: own elaboration.

While analysing the obtained results it should be noted that the thesis which was indicated by the experts as being of the highest importance for the economic growth of the country was T8 - Living conditions and employment opportunities in the country will stop the migration of highly qualified professionals. The determined importance indicator reached the value of 90 (table 2). The importance of the thesis can also be seen in the analysis of individual ratings given by the experts (fig. 3).

Almost all of the respondents (30 people) pointed to high or very high importance of the thesis in the context of the economic growth of the country. The following theses can also be considered of considerable significance: T9 Obtaining education in Poland will ensure high quality of life, T13 - Development of the education system will be focused on promoting smart 
specialisations, T7 - The return from abroad of Polish highly qualified professionals will contribute to economic growth and T3 - The vocational training system will ensure the adjustment of professional qualifications to the rapidly changing needs of the labour market. These theses, together with the $\mathrm{T} 8$ thesis, obtained the highest importance indicator values for the economic growth of the country.
A summary of the experts' opinions on the implementation time of the issues described in the theses is presented in fig. 4. In the opinion of the respondents, the theses which are characterized by the shortest implementation time (until 2023) are T5, T6.

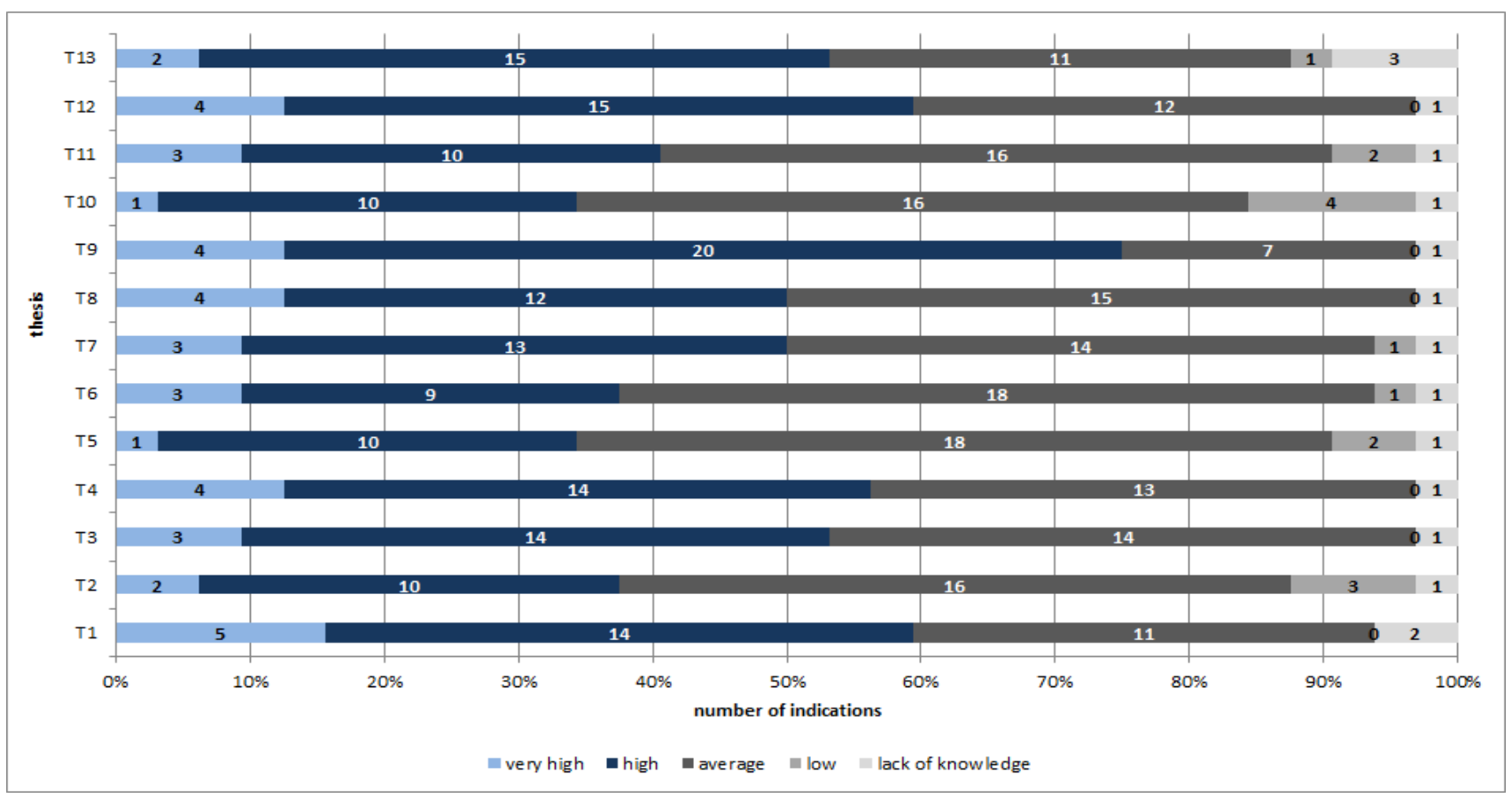

Fig. 2. Degree of knowledge declared by the experts on the issues described in the theses Source: own elaboration.

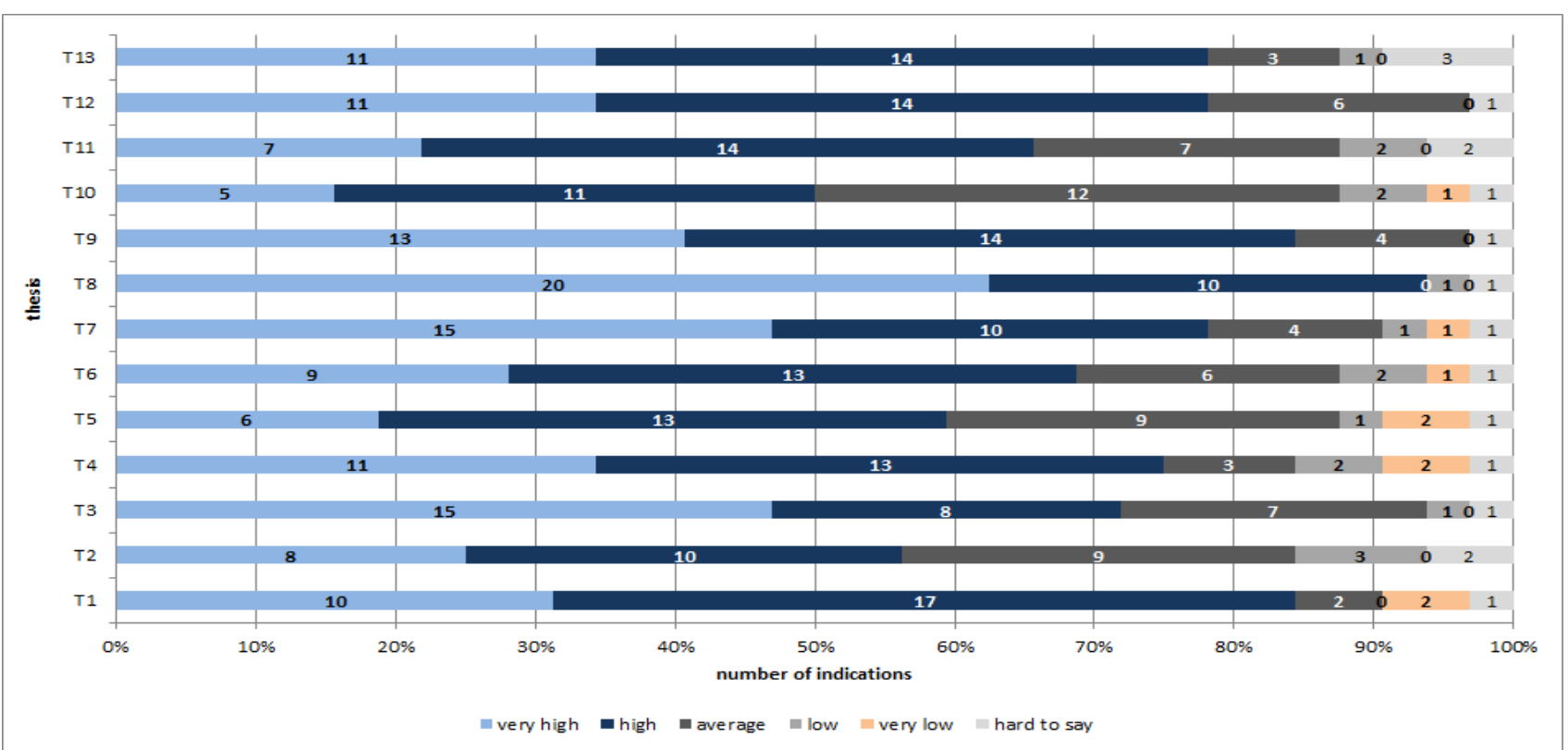

Fig. 3. Significance for the economic growth of the country - summary of the experts' evaluations Source: own elaboration. 


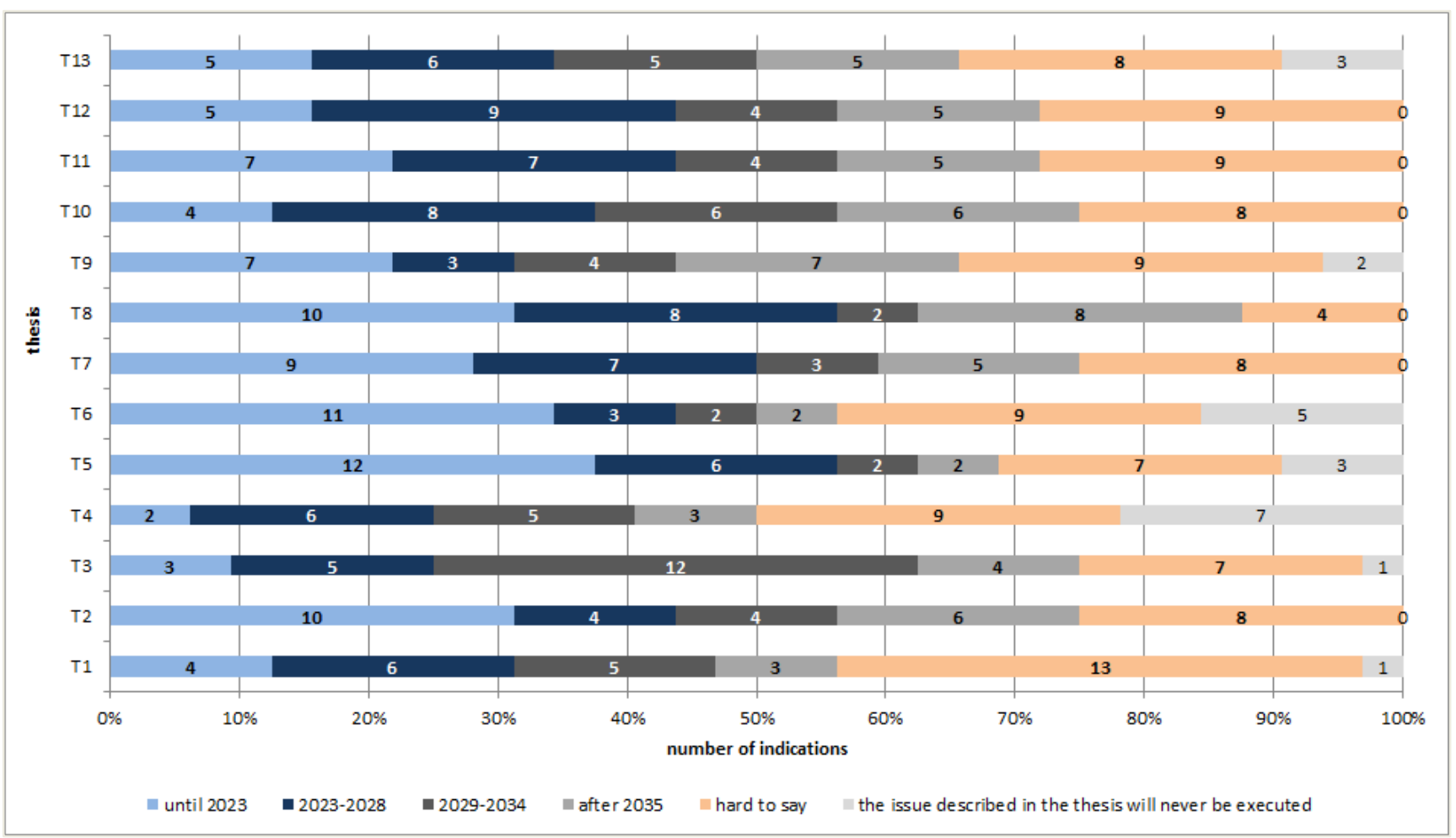

Fig. 4. The experts' estimated implementation time of the issues described in the theses Source: own elaboration.

Table 3. Values of indicators of significance of factors facilitating the implementation of the theses and indicators of significance of barriers hindering the implementation of the theses

\begin{tabular}{|c|c|c|c|c|c|c|c|c|c|c|c|c|c|c|c|c|}
\hline \multirow[b]{2}{*}{$\frac{\frac{n}{8}}{\frac{D}{E}}$} & \multicolumn{9}{|c|}{ Factors conducive to the implementation of the theses $\left(I_{f}\right)$} & \multicolumn{7}{|c|}{ Barriers to the implementation of the theses $\left(I_{b}\right)$} \\
\hline & 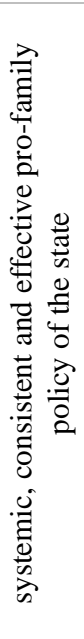 & 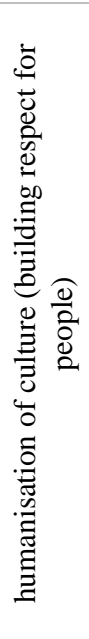 & 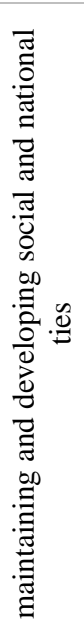 & 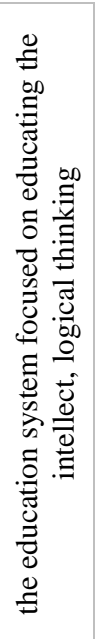 & 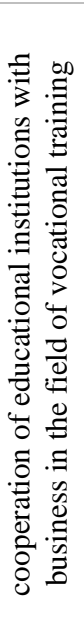 & 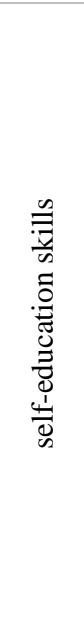 & 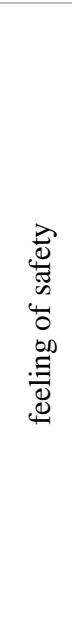 & 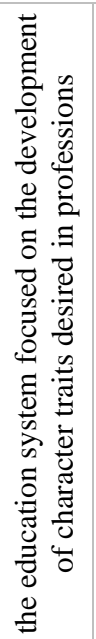 & 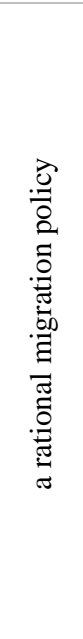 & 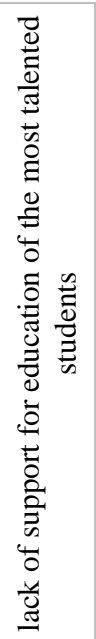 & 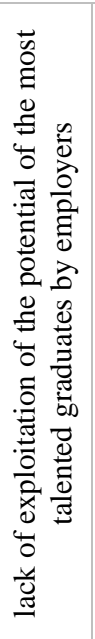 & 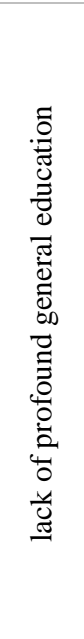 & 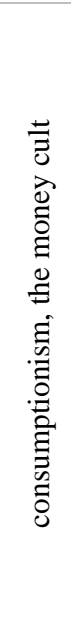 & 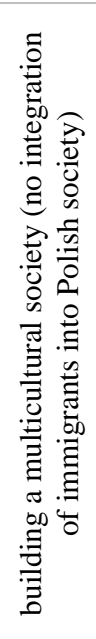 & 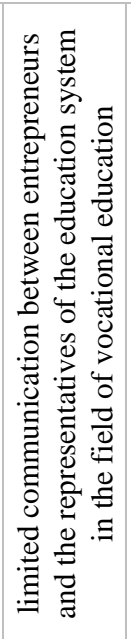 & 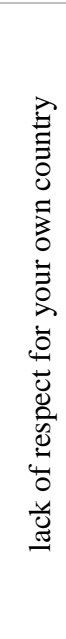 \\
\hline $\mathrm{T} 1$ & 62,1 & 84,7 & 77,4 & 73,4 & 65,3 & 71,0 & 73,3 & 70,2 & 56,7 & 68,5 & 68,5 & 68,5 & 78,2 & 66,4 & 66,1 & 73,3 \\
\hline $\mathrm{T} 2$ & 75,0 & 66,9 & 63,3 & 71,7 & 62,5 & 74,2 & 79,8 & 73,3 & 52,5 & 65,3 & 65,3 & 65,3 & 75,0 & 62,9 & 62,9 & 69,8 \\
\hline $\mathrm{T} 3$ & 47,6 & 55,6 & 52,5 & 80,0 & 86,3 & 75,8 & 56,5 & 82,3 & 57,5 & 79,0 & 77,4 & 73,4 & 55,6 & 52,5 & 79,8 & 50,9 \\
\hline $\mathrm{T} 4$ & 50,0 & 58,3 & 50,0 & 72,4 & 70,4 & 74,1 & 59,3 & 73,1 & 54,8 & 73,2 & 75,0 & 71,6 & 57,0 & 52,8 & 71,2 & 54,0 \\
\hline T5 & 60,8 & 62,1 & 62,1 & 66,4 & 63,3 & 68,1 & 70,8 & 65,8 & 86,7 & 64,2 & 62,5 & 62,1 & 50,0 & 82,5 & 62,9 & 73,3 \\
\hline T6 & 61,7 & 63,4 & 61,7 & 58,3 & 60,8 & 62,9 & 62,9 & 62,9 & 83,6 & 65,0 & 64,7 & 65,5 & 54,3 & 69,6 & 60,3 & 63,4 \\
\hline $\mathrm{T} 7$ & 81,7 & 75,8 & 93,3 & 67,7 & 59,2 & 65,3 & 88,3 & 64,5 & 84,2 & 65,3 & 71,7 & 62,5 & 71,6 & 59,2 & 60,0 & 74,2 \\
\hline T8 & 86,3 & 83,1 & 87,1 & 81,5 & 71,8 & 72,4 & 90,3 & 73,4 & 79,8 & 84,2 & 83,9 & 73,3 & 78,3 & 61,7 & 71,0 & 76,7 \\
\hline T9 & 70,8 & 72,6 & 72,5 & 83,1 & 76,6 & 79,0 & 70,8 & 78,2 & 69,6 & 83,9 & 87,1 & 79,0 & 62,9 & 55,8 & 71,0 & 60,7 \\
\hline T10 & 66,7 & 81,7 & 73,3 & 75,0 & 66,7 & 80,2 & 71,3 & 71,3 & 46,4 & 56,0 & 58,6 & 62,9 & 44,2 & 38,9 & 56,9 & 46,9 \\
\hline T11 & 74,2 & 77,4 & 69,6 & 73,4 & 68,5 & 78,3 & 76,7 & 72,6 & 53,1 & 60,5 & 69,2 & 67,2 & 47,3 & 45,2 & 62,9 & 47,2 \\
\hline T12 & 60,3 & 72,5 & 66,1 & 86,3 & 76,7 & 87,9 & 71,8 & 79,8 & 38,5 & 85,5 & 83,9 & 79,0 & 62,5 & 43,8 & 68,3 & 54,5 \\
\hline T13 & 50,0 & 62,5 & 54,8 & 80,6 & 79,5 & 80,4 & 59,3 & 79,5 & 41,7 & 84,3 & 85,2 & 72,3 & 51,0 & 47,9 & 79,5 & 50,0 \\
\hline
\end{tabular}


The theses with the estimated execution period of 2023-2028 were theses T12, T10 and T8. In the years 2029-2034, the thesis T3 has the greatest chance of being implemented. In turn, the respondents predicted that theses $\mathrm{T} 8$ and $\mathrm{T} 9$ would be implemented after 2035. The implementation period for thesis T1 appeared to be the most difficult for the experts to determine. The highest probability of not executing the issue described in the thesis according to the respondents is in the case of thesis T4.

As indicated in the description of the research methodology during the conducted expert workshops, the authors, together with the experts, indicated factors and barriers to the implementation of the theses relating to labour resources and the future of the labour market in Poland (table 3). The first part of table 3 presents the values of significance indicators, synthesising and organising the results of the experts' indications referring to the degree of influence of particular factors on the possibility of implementing the identified theses. The values of these indicators were calculated according to formula (2).

According to the experts' assessment (table 3), a systemic, consistent and effective pro-family policy of the state has the greatest impact on the issue described in thesis T8, formulated as: living conditions and employment opportunities in the country will stop the migration of highly qualified professionals (the value of the significance indicator is 86.3). In the opinion of the respondents, the factor humanisation of culture (building respect for people) has the most significant influence on the possibility of implementing thesis 2 assuming that educational and professional choices will be independent of the available forms of social assistance, e.g. temporary benefits, family allowances. According to the indications of the respondents, the indicator for this factor assumed a value of 84.7. In the opinion of the experts, the factor maintaining and developing social and national ties has the greatest influence on the probability of execution of thesis 7 (the return from abroad of Polish highly qualified specialists will contribute to economic growth). The value of the significance factor in this case was 93.3. At this point it is also worth emphasising that, in the opinion of the respondents, this factor is characterised by the highest significance factor among all the factors identified for this research. In analysing the strength of the influence of the factor the education system focused on educating the intellect, logical thinking it should be indicated that, according to the experts, it has the greatest influence on the possibility of implementing thesis 12 (the education system will create an entrepreneurial attitude). The value of the indicator in this case was 86.3. Another factor, cooperation of educational institutions with business in the field of vocational training, has the strongest impact on thesis T3, formulated as follows: the vocational education system will ensure the adjustment of professional qualifications to the rapidly changing needs of the labour market (indicator value - 86.3). In turn, as indicated by the respondents, the factor of selfeducation skills has the most significant impact on the issue described in thesis T12 (the education system will create an entrepreneurial attitude). The value of the indicator in this case was 87.9. The feeling of safety factor also had a high impact on the possibility of thesis execution. The experts indicated that it has the most significant impact on thesis T8 (living conditions and employment opportunities in the country will stop the migration of highly qualified specialists - 90.3). In the opinion of the respondents, even greater influence on the issues described in the theses is exerted by the education system focused on the development of character traits desired in professions. The highest value of the significance indicator (82.3) for a given factor was characterized by thesis $\mathrm{T} 3$ assuming that the vocational education system will ensure the adjustment of professional qualifications to the rapidly changing needs of the labour market (indicator value - 86.3). In the opinion of the respondents, a rational migration policy is the factor with the greatest impact on the thesis T5, formulated as follows: the employment of foreigners will not increase unemployment among Poles seeking work (indicator value - 86.7).

The second part of table 3 presents the values of the indicators referring to the importance of the barriers to the implementation of the issues described in individual theses. The values of these importance indicators were calculated according to formula (3).

In the opinion of the experts, the lack of support for education of the most talented students is the barrier that most strongly limits the possibility of executing the issue described in thesis T12 (the education system will create an entrepreneurial attitude). The value of the indicator in this case was 85.5. According to the respondents, lack of exploitation of the potential of the most talented graduates by employers is the barrier which most hinders the realization of thesis T9 assuming that obtaining education in Poland will ensure a high quality of life (indicator value - 87.1). The barrier lack of profound general education is the one that 
limits the chances for implementing thesis T9 (obtaining education in Poland will ensure a high quality of life) and thesis T12 (the education system will create an entrepreneurial attitude). The values of indicators in both cases were 79.9. In the opinion of the experts, consumptionism, the money cult is the barrier that most strongly limits the possibility of executing thesis T8, formulated as: living conditions and employment opportunities in the country will stop the migration of highly qualified specialists (indicator value - 78.3). The respondents, on the other hand, decided that the barrier: building a multicultural society (lack of integration of immigrants with Polish society) makes it most difficult to realize thesis T5 which assumes that the employment of foreigners will not increase unemployment among Poles seeking work (indicator value -82.5 ). The experts' opinion also shows that limited communication between entrepreneurs and the representatives of the education system in the field of vocational education is the barrier that hinders the implementation of thesis T3 (the vocational education system will ensure the adjustment of professional qualifications to the rapidly changing needs of the labour market). The value of the importance indicator in this case was 79.8. The last barrier considered by the respondents is the lack of respect for their own country. The respondents decided that it most strongly limits the possibility of executing thesis T8, formulated in the following manner: living conditions and employment opportunities in the country will stop the migration of highly qualified specialists (indicator value - 76.7).

\section{Discussion and conclusion}

Recent years have brought rapid economic, demographic and social changes on both the global as well as on the Polish market. Contemporary changes in the labour market are incomparable to any of the previous industrial revolutions and are multiplied by the current pandemic situation. Changes are not limited only to technological innovations, but also affect social and cultural spheres. Rapid progress forces employees to constantly redesign their career paths [28].

The future labour market will be shaped by the following megatrends: the technological revolution (digitalization, artificial intelligence, automation, robotics, big data), the new competences and skills that will be required, the cultural changes (work-life balance, sustainability) and demographic shifts (ageing population, urbanisation and migration). All of these trends are closely interconnected as the future of work will be affected not only by modern and disruptive technologies, but also by cultural change altering the preferences, needs and demands of upcoming generations [31].

The outcomes of the research presented in the previous section of the article allowed the authors to get to know the experts' knowledge in relation to the phenomena described in the theses, their importance for the economic growth of the country, experts' estimated implementation time of the issues described in the theses and indicators' values of significance of factors facilitating the implementation of the theses as well as the indicators of significance of barriers hindering their implementation.

The highest level of knowledge of the issue was declared in case of the influence of obtaining education in Poland on the quality of life (the issue discussed in thesis 9). This seems to be not surprising, as the thesis concerns very general relationship.

The thesis which was indicated by the experts as being of the highest importance for the economic growth of the country was T8 - Living conditions and employment opportunities in the country will stop the migration of highly qualified professionals. While initiatives and action are currently being taken to prevent the migration of skilled workers [22], these efforts should be further intensified and expanded.

Both the conducted study and the analysis of the literature have highlighted the importance of education as a factor in achieving a higher quality of life. It is worth noting that the lack of appreciation of acquired qualifications during the education process and insufficient support in the education of the most talented students turned out to be one of the barriers most strongly affecting the outflow of specialists from the country, according to the Delphi study experts.

In the opinion of the respondents, the theses which are characterized by the shortest implementation time (until 2023) are T5, T6 referring to the employment of foreigners in relation to unemployment increase among Poles (T5) and the level of salaries in Poland (T6). These outcomes are also not unanticipated as in the existing published works, one may find publications confirming that the employment of foreigners in Poland largely includes employment in entry-level positions, usually not requiring high qualifications [2], [9].

On the basis of the conducted research, it can be seen that various factors favour or hinder the realization of the theses. It is not possible to distinguish one clear factor that favors or hinders the 
realization of all theses. The influence of the factors mentioned above depends on the phenomena described in theses.

The authors presented the comprehensive research methodology on labour resources and the future of the labour market in Poland and introduced particular research stages allowing to indicate the strategic importance of theses for the economic growth of Poland. They also determined the indicators relating to the degree of influence of factors on the execution of the theses and indicators relating to the importance of barriers to the implementation of the issues raised in the theses of barriers. The formulas to calculate those indicators were also presented by the authors. The whole procedure adopted in the research can be thus applied to investigate those phenomena also in other countries as the results may be interesting for political decision-makers, public administration employees, employees of district and provincial labour offices.

The authors of the study also note the limitations of the method used.

The Delphi method is effective when other methods are not cost-effective or there are limitations that are not easy to overcome using impartial data. However, it should be remembered that in some cases this method may be inappropriate. The use of the Delphi method for testing is unsuitable when: there are objective data; the aim of the study is not to reach an expert consensus; experts are reluctant to participate in the study or are unavailable; the trainers do not have the appropriate knowledge, sometimes to direct the study or are unable to interpret the results [43]. In conclusion, the Delphi method leads to a consensus with a properly developed questionnaire. When using the Delphi method, however, it is important to remember to apply methodological rigours and to follow appropriate procedures. It is worth noting that the proper selection of experts and the appropriate number of rounds of is a crucial part of the research [37]. Such research gives an opportunity to make and verify hypotheses, and allows to look at the research problem from a broad point of view.

\section{References:}

[1] Abdurahmanova A.T., The role of the intellectual approach in the development of creative thinking in students, Innovation in Pedagogy and Psychology, Vol.3, 2020, pp. 25-31.

[2] Bąk-Grabowska, D. \& Majewicz, B., Kształtowanie zatrudnienia $\mathrm{z}$ wykorzystaniem form niestandardowych i angażowaniem pracowników z Ukrainy - przypadek małego przedsiębiorstwa, Przedsiębiorczość $i$ Zarzadzanie, Vol.19, No.8, 2018, pp. 29-42.

[3] Barber, P. \& López-Valcárcel, B. G., Forecasting the need for medical specialists in spain: Application of a system dynamics model, Human Resources for Health, No.8, 2010. doi:10.1186/1478-4491-8-24

[4] Brzezicki, Ł., Grochowska-Subotowicz, E., Jabłoński， R., Jaworski， P., Maślankowski, J., Miszke, T., Raciniewska, M., Wiktor, M., Zielińska, H. Żochowska, A., Kapital ludzki w Polsce w latach 2014-2018, GUS, Warszawa - Gdańsk 2019, online: https://stat.gov.pl/obszary-tematyczne/inneopracowania/inne-opracowania-zbiorcze/kapitalludzki-w-polsce-w-latach-2014-2018,8,7.html.

[5] Chiu, S., Tu, J., Chu, W. \& Chuang, L., Application of delphi method in constructing evaluation indicators of design students' core competencies. Paper presented at the Innovation in Design, Communication and Engineering - Proceedings of the 3rd International Conference on Innovation, Communication and Engineering, ICICE 2014, 2015, pp. 717-720. doi:10.1201/b18737-150

[6] Czerniawska, M. \& Szydło, J., More or Less ProLiberal? A Comparative Analysis of the Attitudes of Young People Entering the Labour Market, European Research Studies Journal, Vol.23, No.3, 2020, pp. 564-580.

[7] Czerniawska, M. \& Szydło, J., The Worldview and Values - Analysing Relations, WSEAS Transactions on Business and Economics, Vol.17, 2020, pp. 594607, doi: 10.37394/23207.2020.17.58.

[8] Dębkowska, K., Regionalny foresight gospodarczy. Scenariusze wzrostu gospodarczego województwa mazowieckiego, ZPWiM, Warszawa 2013.

[9] Duszczyk, M., \& Matuszczyk K., The Employment of Foreigners in Poland and the Labour Market Situation, Central and Eastern European Migration Review, Vol.7, No.2, 2018, pp. 53-68. doi: 10.17467/ceemr.2018.07

[10] Ejdys, J., Regionalny foresight gospodarczy. Scenariusze rozwoju lokalnego województwa mazowieckiego, ZPWiM, Warszawa 2013.

[11] Federowicz, M. (ed.) \& Wojciuk, A. (ed.), Kontynuacja przemian. Raport o stanie edukacji 2011, Instytut Badań Edukacyjnych, Warszawa 2012.

[12] Felisardo, F., Llinàs-Audet, X. \& Améstica-Rivas, L., Competitions in administrator training: A challenge for higher education institutions in Brazil. [Competencias en la formación del administrador: Un reto a las instituciones de enseñanza superior en Brasil] Utopia y Praxis Latinoamericana, Vol.24, No.Extra4, 2019, pp. 13-24.

[13] Flanagan, T., Ashmore, R., Banks, D. \& MacInnes, D., The delphi method: Methodological issues arising from a study examining factors influencing the publication or non-publication of mental health 
nursing research, Mental Health Review Journal, Vol.21, No.2, 2016, pp. 85-94. doi:10.1108/MHRJ-07-2015-0020

[14] Glińska, E., Gudanowska, A., Jarocka, M., Kononiuk, A., Rollnik-Sadowska, E., Samul, J. \& Kozłowska, J., Przyczyny zróżnicowania powiatowych rynków pracy województwa podlaskiego, Wojewódzki Urząd Pracy w Białymstoku, Białystok 2017.

[15] Główny Urząd Statystyczny Urząd Statystyczny w Łodzi, Jakość życia w Polsce w 2015 roku. Wyniki badania spójności społecznej, Studia i analizy statystyczne, Warszawa 2017, online: https://stat.gov.pl/download/gfx/portalinformacyjny/ pl/defaultaktualnosci/5486/4/2/1/jakosc_zycia_w_p olsce_w_2015_roku.pdf.

[16] Gnatzy, T., Warth, J., Gracht, H. \& Darkow, I. L, Validating an innovative real-time Delphi approach - A methodological comparison between real-time and conventional Delphi studies, Technological Forecasting and Social Change, No.78, 2011, pp. 1681-1694. doi:10.1016/j.techfore.2011.04.006

[17] González, J. A. M. \& Kobylińska, U., Influence of personal variables on entrepreneurial intention: A comparative study between Poland and Spain, Engineering Management in Production and Services, Vol.11, No.1, 2019, pp. 68-79. doi:10.2478/emj-2019-0005

[18] Górniak, J. (ed.), Polski rynek pracy - wyzwania $i$ kierunki działań na podstawie badań Bilans Kapitału Ludzkiego 2010-2015, Polska Agencja Rozwoju Przedsiębiorczości, Warszawa - Kraków 2015.

[19] Halicka K. \& Surel D., Evaluation and Selection of Technologies Improving the Quality of Life of Older People, European Research Studies Journal, Vol.2, 2020, pp. 592-611.

[20] Hasson, F., \& Keeney, S., Enhancing rigour in the Delphi technique research, Technological Forecasting and Social Change, No.78, 2011, pp. 1695-1704. doi:10.1016/j.techfore.2011.04.005

[21] Hinojo Lucena, F.J. Aznar Díaz, I. \& Romero Rodríguez, J. M., Human factor and business productivity: An approach from the analysis of cross-cutting competences, InnovarOpen Access, Vol.30, No.76, 2020, pp. 51-62.

[22] Instytut Analiz Rynku Pracy Sp. z o.o., „Drenaż mózgów” czyli migracje potencjału intelektualnego, raport, seria: Monitoring rynku pracy, PARP, 2019 online:

https://www.parp.gov.pl/storage/publications/pdf/M igracjawykwalifikowanychpracownikow_190813.pd f (29.09.2020).

[23] Kapias, M. \& Polok, G., Etos pracy w perspektywie badań longituidalnych nad preferencjami aksjologicznymi studentów UE Katowice, Transformacja współczesnej gospodarki jako przedmiot badań ekonomicznych, No. 187, 2014, pp. 156-170.
[24] Kaźmierczyk J. \& Chinalska A., Flexible forms of employment, an opportunity or a curse for the modern economy? Case study: banks in Poland, Entrepreneurship and Sustainability Issues Vol.6, No.2, 2018, pp. 782-798. doi:10.9770/jesi.2018.6.2(21)

[25] Kogut-Jaworska, M. \& Ociepa-Kicińska, E., Smart Specialisation as a Strategy for Implementing the Regional Innovation Development Policy - Poland Case Study, Sustainability, Vol.12, No.19, 2020, pp. 1-21. doi:10.3390/su12197986

[26] Konieczna-Sałamatin, J. (ed.), Imigranci o wysokich kwalifikacjach na polskim rynku pracy. Raport $z$ badań 2014-2015, iSEE - Instytut SpołecznoEkonomicznych Ekspertyz i Fundacja "Nasz Wybór", Warszawa 2015.

[27] Kononiuk A., Pająk A., Gudanowska A. E., Magruk A., Rollnik-Sadowska E., Kozłowska J. \& SacioSzymańska A., Foresight for Career Development, Foresight and STI Governance, Vol.14, No.2, 2019, pp. $\quad 88-104$ doi: $10.17323 / 2500-$ 2597.2020.2.88.104

[28] Kononiuk, A. (ed.), Pająk, A. (ed.), Gudanowska, A., Kozłowska, J., Magruk, A., Rollnik-Sadowska, E. \& Sacio-Szymańska, A., Projektowanie kariery zawodowej - perspektywa badań foresightowych, Oficyna Wydawnicza Politechniki Białostockiej, Białystok 2019. doi: 10.24427/978-83-66391-16-1

[29] Kowalewska, A. \& Głuszyński, J., Application of the Delphi Method in the National Foresight Program „Poland 2020” (in Polish), Pentor Research International, Warsaw 2009.

[30] Landeta, J., Barrutia, J. \& Lertxundi, A., Hybrid Delphi: a methodology to facilitate contribution from experts in professional contexts, Technological Forecasting and Social Change, No.78, 2011, pp. 1629-1641. doi:10.1016/j.techfore.2011.03.009

[31] Making the future of work inclusive of people with disabilities, The ILO Global Business and Disability Network, 2019.

[32] Mamaqi, X., Miguel, J. \& Olavel, P., The eDELPHI method to test the importance competence and skills: Case of the lifelong learning spanish trainers, World Academy of Science, Engineering and Technology, Vol.42, 2010, pp. 1494-1504.

[33] Mirata, V., Hirt, F., Bergamin, P., \& van der Westhuizen, C., Challenges and contexts in establishing adaptive learning in higher education: Findings from a delphi study, International Journal of Educational Technology in Higher Education, Vol.17, No.1, 2020. doi:10.1186/s41239-02000209-y.

[34] Moreno, E. S. \& De Roda, A. B. L., Social risk factors in Spanish youth and their impact on selfconcept construction, Spanish Journal of Psychology, Vol.10, No.2, 2007, pp. 328-337. doi:10.1017/S1138741600006594.

[35] Nazarko, J. Regionalny foresight gospodarczy. Metodologia $i$ instrumentarium badawcze, Związek 
Pracodawców Warszawy i Mazowsza, Warszawa 2013.

[36] Nowak H., The Role of the Polish Higher Education System in the Development of Entrepreneurship, Entrepreneurial Business and Economics Review, Vol.4(4), 2016, pp. 43-59, doi: 10.15678/EBER.2016.040104.

[37] Powell C., The Delphi technique: myths and realities, Journal of Advanced Nursing, Vol.41, No.4, 2003, pp. 376-382.

[38] Rachwał T., Entrepreneurship in School in the Conditions of the Education System Reform in Poland - a Voice in the Discussion on the Directions of Change, Przedsiębiorczość - Edukacja [Entrepreneurship - Education], Vol.13, 2017, pp. 330-339. doi: 10.24917/20833296.13.24

[39] Radziszewski, P., Nazarko, J., Vilutiene, T., Dębkowska, K., Ejdys, J., Gudanowska, A., Halicka, K., Kilon, J., Kononiuk, A, Kowalski, K. J., Król, J. B., Nazarko, Ł. \& Sarnowski, M., Future trends in road pavement technologies development in the context of environmental protection, Baltic Journal of Road and Bridge Engineering, Vol.11, No.2, 2016, pp. 160-168. doi:10.3846/bjrbe.2016.19

[40] Santoso, H. B. \& Hadi Putra, P. O., Bridging the Gap between IT Graduate Profiles and Job Requirements: A Work in Progress, 2017 7th World Eng. Educ. Forum, pp. 145-148, 2017. doi:10.1109/WEEF.2017.8467146

[41] Sazonenka, Y. \& Rollnik-Sadowska, E., Young People in the EU - National and Regional Dimensions, Przedsiębiorczość $i$ zarządzanie, Vol.19, No.3, pp. 201-215.

[42] Siderska, J., Robotic Process Automation - a driver of digital transformation? Engineering Management in Production and Services, Vol.12, No.2, 2020, pp. 21-31. doi:10.2478/emj-2020-0009

[43] Skinner R., Nelson R., Chin W. W. \& Land L., The Delphi Method Research Strategy in Studies of Information Systems, Communications of the Association for Information Systems, Vol.37, 2015, pp. 31-63.

[44] Stasiak, J., System edukacji wobec wyzwań rynku pracy w Polsce, Acta Universitatis Lodziensis. Folia Oeconomica, Vol.248, 2011, pp. 343-357.

[45] Szpilko, D., The use of Delphi method in the process of building a tourism development strategy in the region, Ekonomia $i$ Zarzadzanie, Vol.6, No.4, 2014, pp. 329-346. doi:10.12846/j.em.2014.04.24

[46] Szreder, M., Wykształcenie a długość i jakość życia, Polityka społeczna, No.7, 2013, pp. 1-5.

[47] Szydło J., Grześ-Bukłaho J., Relations between National and Oanisational Culture-Case Study, Sustainability, vol.12, No.4, 2020, pp. 1-22, 1522, doi:10.3390/su12041522

[48] Tiwari, P., Sadeghi, J. K. \& Eseonu, C., A sustainable lean production framework with a case implementation: Practice-based view theory, Journal of Cleaner Production, Vol.277, 2020. doi:10.1016/j.jclepro.2020.123078
[49] Umurov Z., Technology for preparing educational and cognitive problems for primary school students, International Journal of Advanced Science and Technology, Vol.29, No.5(10), 2020, pp. 14651471.

[50] Winogrodzka, D. \& Mleczko, I., Migracja płynna a prekaryzacja pracy. Przykłady doświadczeń zawodowych młodych migrantów $\mathrm{z}$ wybranych miast średniej wielkości w Polsce, Studia Migracyjne - Przegląd Polonijny, Vol.1, No.1, 2019, pp. 85-106. doi: 10.4467/25444972SMPP.19.004.10254

\section{Creative Commons Attribution License 4.0 (Attribution 4.0 International, CC BY 4.0)}

This article is published under the terms of the Creative Commons Attribution License 4.0 https://creativecommons.org/licenses/by/4.0/deed.en_US 